\title{
PLANNING STRATEGIES FOR STORMWATER MANAGEMENT FOR URBAN AREAS: LESSONS FOR INDIA
}

\author{
Prerna Jasuja ${ }^{1}$ and Esha Bhatnagar ${ }^{2}$ \\ 1, 2 Research Scholars, Department of Architecture and Planning, \\ Malaviya National Institute of Technology, Jaipur (Raj), India \\ Correspondence Author Email: pjasuja00@gmail.com
}

\begin{abstract}
How to cite this paper:
Jasuja, Prerna and Bhatnagar, Esha (2021) Planning strategies for stormwater management for urban areas: Lessons for Journal of Global Resources, Vol. 07 (02)
\end{abstract}

DOI:

10.46587/JGR.2021.v07i02.011

Received: 21 March 2021 Reviewed: 10 April 2021 Revised: 26 April 2021

Final Accepted: 26 May 2021

\begin{abstract}
With the growing population and increasing water demand for various purposes in urban areas, the cities fall prey to the water crisis and management issues which include three components, namely freshwater supply, wastewater treatment, and stormwater management. Urban stormwater is surface runoff generated during any rain or snowmelt. Stormwater management has shifted from being a technical problem handled by engineers at water utilities to close integration with urban planning in the USA, Singapore, and China. This paper highlights such practices in these three countries, taking one of their implemented examples. It intends to discuss and analyze the integration within urban plans of blue and green infrastructure and the artificial drainage system in urban areas to maintain stormwater quantity, quality, water security, and means to keep minimal damage to nature post-urban development. Indian cities have yet to address the incorporation of Stormwater management with their spatial planning. The strategies applied by the three countries can be used as a learning lesson in the Indian context.
\end{abstract}

Keywords: Stormwater Management, Water Sensitive

Planning, Blue-Green Infrastructure
OPEN O ACCESS

Freely available Online www.isdesr.org 


\section{Introduction}

Urban Stormwater is surface runoff generated during any rain or snowmelt. Stormwater management is essential for maintaining the natural hydrological cycle. (Nahar, et al., 2019) It aims to reduce the runoff and associated soil erosion in streams or lakes, restore them to the original normality, support the human requirements, and recharge the groundwater, aiding the city's development. (Boulomytis, et al., 2017)It is necessary to protect the quality of water that reaches the aquifers and water bodies downstream. The pollutants picked up with stormwater in Urban land use, if not checked, could damage the water bodies and groundwater quality and sub-surface water reserves. (Aryal \& Naidu, 2010)Stormwater management is necessary to prevent the risk of flooding \& associated economic and life losses. (Nahar, et al., 2019)Stormwater management practices can ensure urban water security. Stormwater as an asset can make cities self-sustainable with surface or sub-surface collection groundwater recharge. ( Matto, et al., 2019).

There is a need to consider stormwater management strategies as a prerequisite of planning, and countries need to encourage these practices to curb water scarcity. (UNWater, 2007) Indian cities face the issue of stormwater quality and quantity management. India is the $13^{\text {th }}$ most water-stressed country in the world, according to the WRI study of 2013. NITI Aayog in 2018 declared that the country is suffering from the worst water crisis . (NITI Aayog, 2018) India can learn from other countries that have a good approach towards stormwater management.

\section{Methodology}

Three countries with an upstanding approach towards stormwater management were selected in this study, namely, the USA's Low impact development, Singapore's Active Beautiful Clean Program by Public Utility Board, and China's Sponge city concept. These countries have been selected because of their exhaustive indicators and norms in integration with urban planning for stormwater management. For understanding the approach towards stormwater management in each country, the national and local guidelines by environment agency, stormwater manuals, groundwater recharge guidelines, with a case study of one city, were studied. Stormwater quantity, and quality management, water security, and approach to keep minimal damage to nature post-urban development within an urban area were considered as fixed parameters on which the analysis was done for each country. Lastly, the strategies were recommended in the Indian context for integrated stormwater management plans.

\section{Literature Study \\ USA}

Stormwater management as a concept was introduced in 1972, under the Best Management Practices, later modified to low impact development or green infrastructure terminology. The country has various codes within different cities related to stormwater. EPA has the authority to form and implement stormwater regulations. (USEPA, 2020) Approach from United states Environment Protection Agency - Stormwater management Practices, Smart growth program, National Pollutant Discharge Elimination System (NPDES) Stormwater program, Groundwater protection Strategy, Groundwater action plan, National management measures to Control Nonpoint Source Pollution from Urban areas were reviewed, and urban planning strategies were enlisted. The Watershed approach considering rainfall, soil, hydrogeological conditions exist in EPA guidelines for stormwater management. 
Washington City: The city has an area of $177 \mathrm{sq} . \mathrm{km}$. and receives $664 \mathrm{~mm}$ rainfall annually. (Weather-US, 2020) The town relies on the Potomac River for a water supply for a population of 7,00,000 approximately. ( DC Water, 2020) ( US Census Bureau, 2019) Due to geographical conditions with multiple watersheds, stormwater runoff from West Virginia and Pennsylvania contributes to river water quality in Washington DC. (DC water, 2020). The soil and hydrogeology of the region show that most of the land is suitable for recharge. (Johnston, 1964) The city has a combined sewer system in some areas. It has taken up green infrastructure measures under the Anacostia river clean plan to check the stormwater quality and stormwater quantity for managing extreme rainfall with the provision under land-use plans. ( DC office of planning, 2020) The scenario is similar to the Indian context as most Indian cities have combined conveyance of sewer and stormwater and face urban flooding.

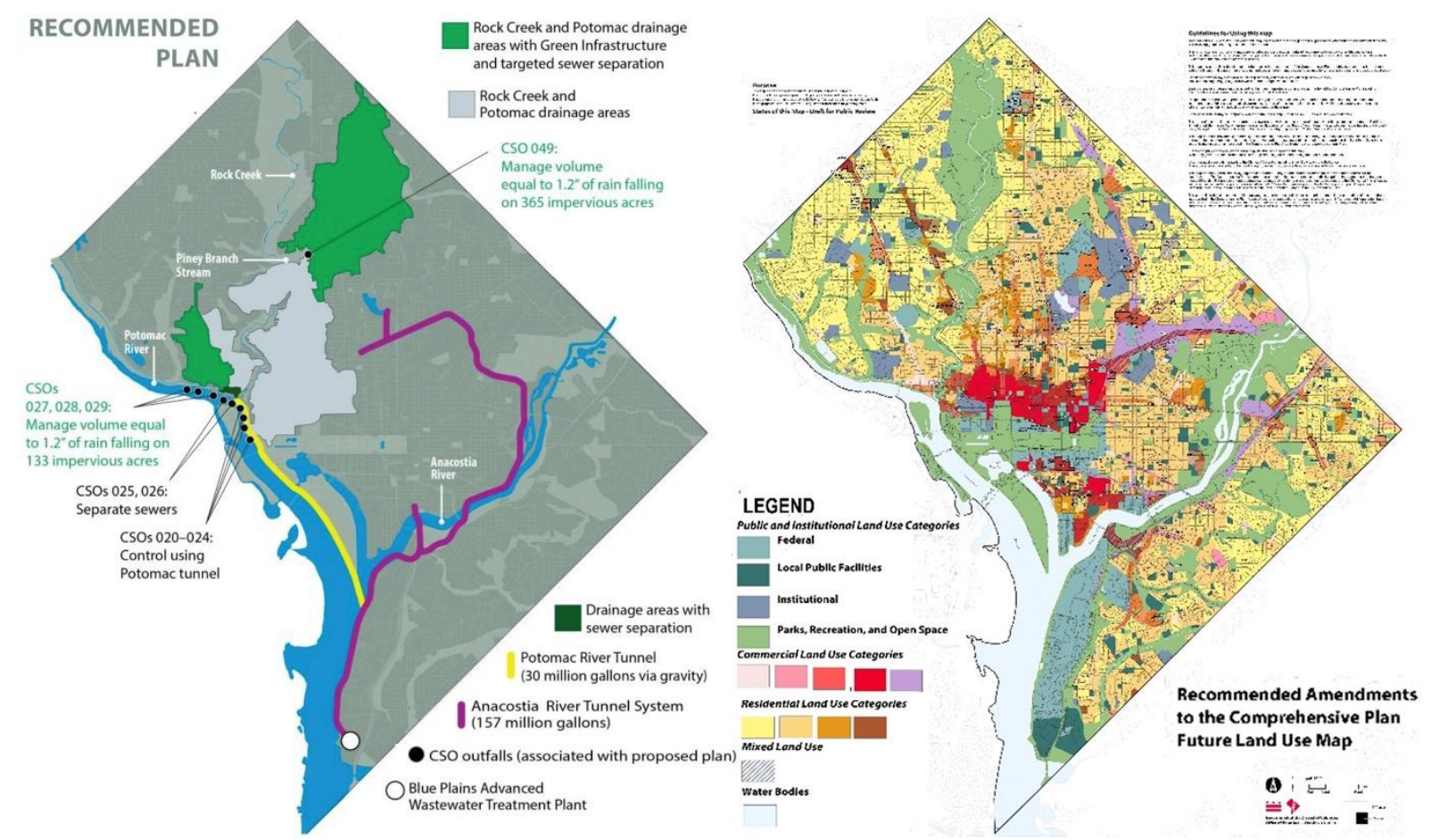

Figure 01: shows the map of Washington DC Green infrastructure planning in areas with the combined sewer system (Left) \& shows the map of Recommended Land use with green infrastructure within Public and institutional land use

Source left: (DC Water, 2020), right: (DC office of planning, 2020)

\section{Strategies adopted in the USA for Stormwater management and the urban planning tools used -}

1. Minimizing damage to nature: Conservation of water bodies, streams, forests in the land use plans and providing adequate buffers near streams has been mentioned in USEPA guidelines to ensure minimum damage post-urban development. There is a set of guidelines by EPA for local bodies for quality and quantity management of stormwater. (USEPA, 2020) (Department of Energy and Environment, 2020)

2. Stormwater quality: The EPA suggests the urban plans have compact development to minimize the impact on the regional water quality as natural areas have intrinsic values that cannot be retained by simple green infrastructure BMP (USEPA, 2006). EPA suggests the use of Buffers along the creeks and stormwater drains to protect from point source pollution, but the width has not been mentioned. Land use plans can be used to demarcate buffers, along with allocating possible areas for the industries 
and other surface polluting establishments and checking the discharge water quality. Land use maps should be prepared by coordinating with the hydrological and soil maps of the region, which include depth of groundwater, site topography, and contributing drainage area study, etc. Best management practices could be incorporated by using such physical features. (District department of environment, Washington DC, 2020) For instance, the Stormwater Retention Credit Trading Program exists at the municipal level for reducing harmful stormwater runoff on-site by installing green infrastructure. These credits can be sold to the sites where owners don't want to plan with the provisions. (Department of Energy and Environment, 2020) Separating the sewage and stormwater system can help in improving its quality which has been stated in the DC's stormwater plan, which aims to improve its urban waterway's health. Further in the city, Washington, land use plans allocate an area for green infrastructure for checking stormwater quality. (District department of environment, Washington DC, 2020)

3. Stormwater quantity: Stormwater drains should be constructed by utilizing hydrology, topography, natural streams, and water bodies of the region. (USEPA, 2008). Incentivising citizens through Stormwater Retention Credit Trading Program for future projects and redevelopment projects to reduce runoff from sites can be another means to maintain a stormwater quantity check. (District department of environment, Washington DC, 2020) For instance, major land-disturbing projects are required to retain 1.2 " and 0.8 " of rainfall on-site, respectively (Center for Watershed protection, 2020). This implies that volume-based controls for the discharge-based regulations need to be implemented to reduce stormwater runoff through municipal regulations or building bye-laws. Solid waste management and separate sewer system to ensure the undisrupted flow of stormwater in stormwater drains.

4. Water security: USEPA has suggested safeguarding recharge areas in master plans by reserving them for blue/green cover for stormwater harvesting. (USEPA, 1984) Local area zoning, lot sizes for development have been regulated into a few localities to prevent intensive residential or commercial development over recharge areas under groundwater protection strategy. Such decisions need to be taken at the onset of land use planning for the city.

\section{Singapore}

The country has an area of $725 \mathrm{sq}$. $\mathrm{km}$. and receives an annual rainfall of $2430 \mathrm{~mm}$. (Singapore Land Authority, 2019) (PUB, 2014). The country is one of the most densely populated cities, with a population of $57,00,000$ (Singapore Government, 2020). The country has relied on high rise high-density development because of land scarcity which gives it ease in providing infrastructure. The island country has no aquifer, so the collection of runoffs is the optimum solution for fighting water scarcity. The public utility board is the agency to manage the stormwater. Singapore relies on Malaysia (raw water), collected stormwater, treated wastewater, and desalination to meet its water demand. Singapore has implemented stormwater management successfully and has used it for potable consumption on a large scale. "Source-Pathway-Receptor" strategy by the Public Utility Board (PUB) seeks to develop catchment-wide solutions. (URA, 2019) (PUB, 2014)The city has utilized its runoff as a resource by checking quantity and quality. The model is suitable for island cities, which lack aquifers. (PUB, 2019) (URA, 2019)Indian cities can learn from Singapore's example to protect stormwater as a resource. Indian cities could adopt the measures for stormwater quality with 
the aquifer. Stormwater management closely integrates reservoirs and canals into the city landscape for community and biodiversity in the city.

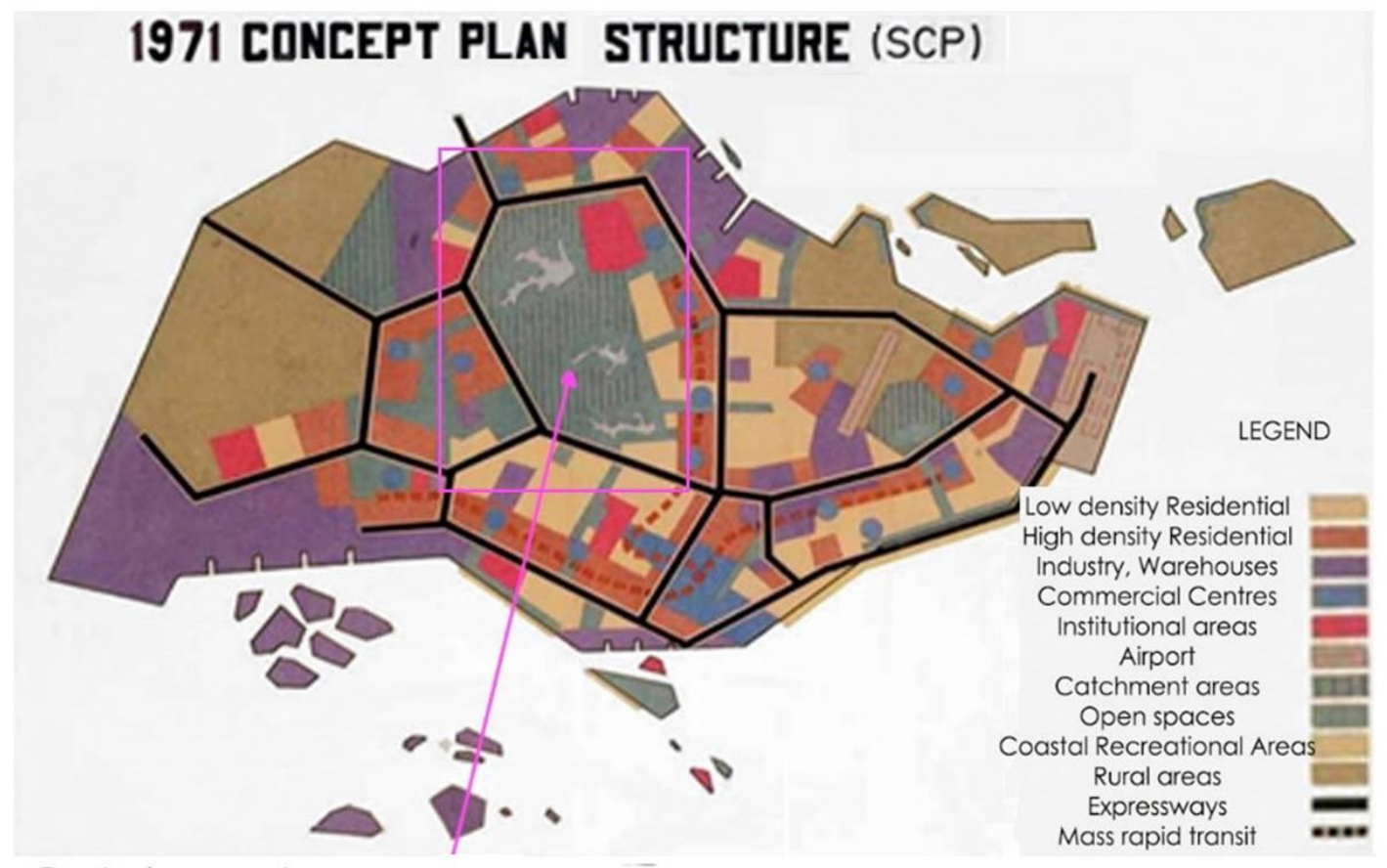

Catchment areas

Figure 02: showing the map of Singapore with protected catchments preserved in the Master plan from 1971. (Source: Author based on info - (URA, 2019)

\section{Strategies adopted in Singapore for Stormwater management and the urban planning tools used}

1. Minimizing damage to natural features: By delineating the catchment areas in the master plans, Singapore has achieved catchment-based strategic planning with protected areas and reservoir placement by considering the hydrogeological and geographical aspects, including the local precipitation.

2. Stormwater Quality: This can be achieved by a separate conveyance system of stormwater and sewage with adequate wastewater provision. For instance, Singapore has a separate provision of collection and treatment for sewage and stormwater, with precautions being taken at the source, carriers, and receiving areas to minimize pollution has been made in the city. Nature-based solutions can be used for recreational land use and urban greens to improve the quality through building by-laws, city roads, and waterways. "Source-Pathway-Receptor strategy" has been adopted for decentralized treatment for stormwater quality. It addresses the stormwater collection network (the pathways for water), the source of surface runoff, and areas where floods may occur (receptor). (PUB, 2014) The solid waste management system should be separated from the stormwater system. Land-use control on non-polluting industries with protected catchments for stormwater harvesting and demarcated protected catchments with no construction allowed can assure the least contamination of the water.

3. Stormwater quantity: Preparation of Infrastructure plans by incorporating the topography and green cover of the region. Local area plans should demarcate the canals and streams and preserve them with buffer according to peak runoff. Singapore 
uses most of nature's drainage and constructed hierarchy of manmade drains, diversion canals - widening and deepening of drains and canal with buffer provision to check issues of flooding and waterlogging. It is also managing peak runoff by "reduction at source" strategy through the implementation of on-site detention measures before discharging it to the public drainage system for all developments greater than or equal to 0.002 sq. $\mathrm{km}$ (PUB, 2014)

4. Water security: 1971 Concept Master Plan and Master plan 2008 of Singapore have protected catchments to harvest rainwater marked within the land use. (URA, 2019) Delineated protected catchments help in reducing the impact from infrastructure projects.

\section{China}

China introduced the concept of Sponge Cities in 2013. It Is stormwater could be conserved, infiltrated, and purified for reuse, with the benefits of reducing flood risks rectify groundwater pollution, and increasing water security. (Ministry of Ecology \& Environment, China, 2017) Qunli Stormwater Wetland Park is one of the numerous initiatives taken under China's sponge city plan. The country's approach is similar to the USA to mimic natural processes to improve stormwater quality.

\section{Qunli Stormwater Wetland Park, Harbin City, China}

Qunli town in Haerbin falls under the Songhua river basin. Qunli town has an area of $27.33 \mathrm{sq}$. $\mathrm{km}$. The annual rainfall is $567 \mathrm{~mm}$. The project Turenscape Firm designed the Qunli Stormwater park project that is spread over $0.3 \mathrm{sq}$. $\mathrm{km}$. Harbin city faces groundwater pollution due to urban land use. Before this project, the town suffered through frequent floods and waterlogging $.16 .4 \%$ of the developed land comprised green permeable space; after this project, the three sq. $\mathrm{Km}$. of the area got rid of floods which is ten times the park area. (Turenscape, 2014)

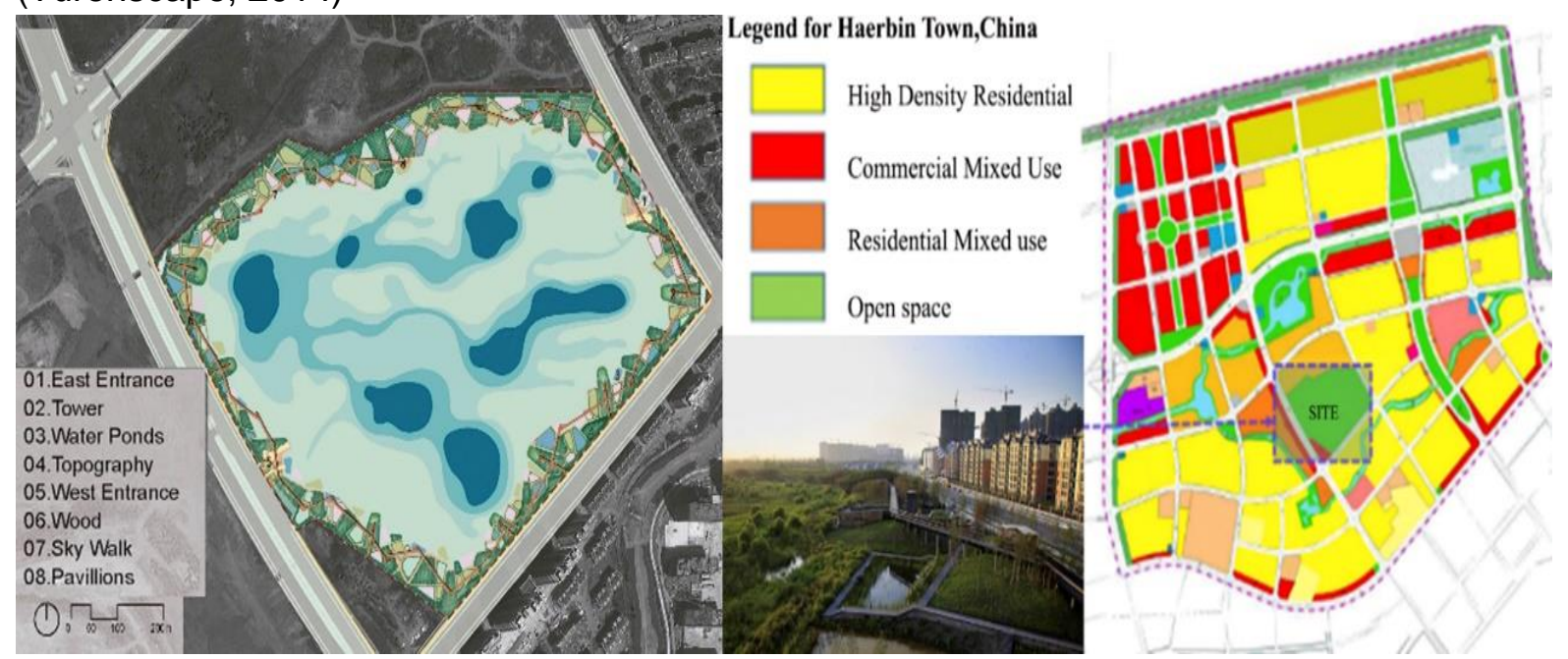

Figure 03: showing the concept of Qunli stormwater wetland park (left) and land use Plan of Qunli town (right). (Source: (Turenscape, 2014) (Turenscape, 2014)

A network of pipes runs on the wetland periphery, which collects the stormwater, filters it through the ponds, and releases it to the park. The project comprises stormwater collection, cleansing, storing, and recharging of the aquifer. The ecosystem of the wetland has recovered with the inculcation of native plantations in the ponds. 


\section{Strategies adopted in China for Stormwater management and the urban planning tools used}

1. Minimizing damage to natural features: Utilizing green open spaces, wetlands, and urban gardens to manage stormwater quality and quantity considering topography and soil conditions. Land use Plan to allocate greens for stormwater in Master plan.

2. Stormwater Quality: The project comprises stormwater collection, cleansing, storing, and recharging of the aquifer. Treatment in the source, pathway, and receptor through nature-based solutions under Open space. Land-use allocation of space for a constructed wetland in land use plan for collection, cleansing, storing, and recharging. China is a developing country and aims to improve wastewater infrastructure and solid waste management in its national plans. There is no specific guideline for discharge standards. Solid waste management and sewage system are checked under the national Songhua River Basin Pollution Control Master Plan to prevent stormwater pollution. (SRBPCMP) (ADB, 2008) Solid waste and separate conveyance of stormwater and sewage need to be checked in Infrastructure plans.

3. Stormwater quantity: Increasing Stormwater coverage is addressed in National plans. The country targets $80 \%$ of urban areas collecting $70 \%$ of the rainwater by 2030 by Sponge city concept $10 \%$ of green sponge has solved flooding in the Qunli city. (ADB, 2008) Taking the opportunity of existing green spaces and planning sponges for stormwater to manage quantity. Enhancing drainage capacities to manage stormwater quantity has been addressed under the National Plans. Adequate Stormwater infrastructure

4. Water security: Sponge city concept aims at replenishing groundwater by naturally treating stormwater infiltration. The Qunli wetland currently has a filtrating and retaining capacity of $500,000 \mathrm{~m}^{3}$. The data regarding recharge was not available for the city. (Turenscape, 2014) Groundwater recharge through planned sponges in the master plan.

\section{Analysis from the Case Studies}

1. Minimizing damage to natural features: In all three countries, stormwater management is being implemented by the catchment or watershed approach by considering local topography, hydrogeology, and soil conditions. Approach of USEPA and Singapore's PUB to reduce the impact of development by minimizing the damage to natural lands, forests and protecting the water bodies and streams with adequate buffers. USEPA promotes the preservation of recharge suitable areas, and Singapore, through protected catchments, shows how to minimize the impact on nature. Though density is a BMP by the USA, Indian cities can adopt compact development by checking density in the master plan for ease in infrastructure provision for urban services.

2. Stormwater Quality: The three countries have an approach of improving wastewater infrastructure with a separate conveyance system of stormwater and sewage and checking solid waste management by the urban local body to ensure stormwater quality. There is a variation in discharge standards in the countries. In India, municipal solid waste management by local bodies should be ensured for stormwater quality, and it has significantly improved after Swach Bharat Abhiyan. However, the country has to improve its wastewater infrastructure significantly. Allocation of spaces for green infrastructure might vary in urban plans according to goals, standards, and technology 
applied to achieve the same. Nature-based solutions for source, pathways, and receptors could be planned within the master plans.

3. Stormwater quantity: The three case studies encourage preserving the natural drainage channels and water bodies, utilizing them to collect all stormwater runoff along with human-made drains. India can overlook the possibility of Sponges within the city, which can help in the issue of urban flooding and associated losses. Solid waste dumping and sewage dumping into waterways are discouraged as it reduces the carrying capacity of the drains. India should promote on-site rainwater harvesting for large-scale developments and reuse stormwater on sites by incentives on stormwater cess or credits through building by-laws or municipal regulations to reduce the existing stormwater infrastructure system load.

4. Water security: After the geological assessment, safeguarding high recharge areas in master plans for stormwater harvesting and checking the development as seen in the USEPA guidelines is the most appropriate strategy. The proposed development within the master plan will stay for years, and sensitive recharge areas would be hard to revive if not preserved. This approach requires institutional integration between various departments such as the groundwater department and development authorities. In China's sponge city, the groundwater recharge approach by restoring the wetland and utilizing urban greens can be adopted in India. In case of no aquifer availability, stormwater storage could be adopted, as seen in Singapore. Singapore's model could be adopted in the island and coastal cities where recharge conditions are not present.

\section{Conclusion}

The strategies can be applied if stormwater management is addressed in the initial phase of master planning. The countries look forwards to blue-green infrastructure or nature-based measures instead of the conventional approach of constructing tunnels and drains. The approach as seen will vary because of geological, soil, topographical differences in the watersheds. Economic efficiency \& environmental sustainability are achievable through such strategies. There is a need to integrate such strategies in urban planning through various tools and perspective plans such as master plans, city infrastructure plans, and building bye-laws with the proper framework in India.

\section{References}

1. DC office of planning, 2020. Recommended Amendments to the comprehensive Landuse plan(Draft). [Online] Available at: https://plandc.dc.gov/sites/default/files/ dc/sites/ Comprehensiveplan/publication/ attachments/LUAmendmentsPublicDraft101019.pdf

2. DC Water, 2020. From the Potomac to your Pipes. [Online] Available at: https://www.dcwater.com/drinking-water

3. Matto, M., Kumar, M., Joshi, S. \& Rohilla, S. K., 2019. Urban water Sustainability, New Delhi: CSE,MoHUA.

4. US Census Bureau, 2019. QuickFacts District of Columbia. [Online] Available at: https://www.census.gov/quickfacts/DC

5. ADB, 2008. ADB's Contribution to Pollution Control in the Songhua River Basin. [Online].

6. Aryal, R. \& Naidu, R., 2010. Urban Stormwater quality and Treatment. Korean Journal of Chemical Engineering, pp. 1343-1359.

7. Boulomytis, V., Zuffo, A. C. \& Alam , M. I., 2017. Hydrological impacts of urban developments: Modelling and decision-making concepts. Theoretical and Empirical Researches in Urban Management, pp. 5-19.

8. Center for Watershed protection, 2020. Stormwater for Sale: Washington, DC's Stormwater Retention Credit Program. [Online] Available at: https://www.michigan.gov/documents/deq/deqtou-GLSL-GIC-Hoffman-DCstormwater_578495_7.pdf 
9. DC office of planning, 2020. Recommended Amendments to the comprehensive Landuse plan(Draft). [Online] Available at:

https://plandc.dc.gov/sites/default/files/dc/sites/Comprehensiveplan/publication/attachments/LUAm endmentsPublicDraft101019.pdf

10. DC water, 2020. DC waters. [Online] Available at: https://www.dcwater.com/protecting-ourwaterways

11. DC Water, 2020. Long Term Control Plan Modification for Green Infrastructure, District of Columbia : District of Columbia Water and Sewer Authority Washington, DC.

12. Department of Energy and Environment, 2020. Water. [Online] Available at: https://sustainable.dc.gov/page/water

13. District department of environment, Washington DC, 2020. DC STORMWATER PLAN. [Online] Available at: https://dcstormwaterplan.org/wpcontent/uploads/ExecutiveSummary_InteractivePDF.pdf

14. EPA, 2005. National Management Measures Guidance to Control Nonpoint Source Pollution from Urban Areas, s.I.: EPA.

15. Johnston, P. M., 1964. Geology and Ground-Water Resources of Washington, D.C., and Vicinity, DC: UNITED STATES GOVERNMENT PRINTING OFFICE, WASHINGTON : 1964.

16. Ministry of Ecology \& Environment, China, 2017. State Of Ecology \& Environment Report Review, s.l.: Ministry of Ecology \& Environment, China.

17. Nahar, J., Liu, S., Liu, J. \& Shah, S. L., 2019. Improved storm water management through irrigation rescheduling for city parks. Control Engineering Practice Vol 87, pp. 111-121.

18. National Research Council 2009, 2009. Urban Stormwater Management in the United States, s.I.: The National Academies Press.

19. NITI Aayog, 2018. Composite water management Index, s.I.: s.n.

20. PUB, 2014. Managing stormwater for our future, Singapore: PUB.

21. PUB, 2019. [Online] Available at: https://www.pub.gov.sg/Publishinglmages/Reservoir_Blue_Map_SG.png

22. Singapore Government, 2020. Department of Statistics Available at: https://www.singstat.gov.sg/modules/infographics/population

23. Singapore Land Authority, 2019. Total land area of Singapore. [Online] Available at: https://data.gov.sg/dataset/total-land-area-of-singapore

24. Turenscape, 2014. Qunli Stormwater Park: A Green Sponge For A Water-Resilient City. [Online] Available at: https://www.turenscape.com/en/project/detail/435.html

25. Turenscape, 2014. Urban Ecology. [Online] Available at: https://urbanecologycmu.wordpress.com/2016/10/15/case-study-qunli-stormwater-park/

26. UNWater, 2007. Coping with water scarcity - Challenge of the twenty-first century, s.I.: UN Water.

27. URA, 2019. Previous Master plans. [Online] Available at: https://www.ura.gov.sg/Corporate/Planning/Master-Plan/Previous-Master-Plans

28. USEPA, 1984. Ground-Water Protection Strategy, Washington DC: USEPA.

29. USEPA, 2006. PROTECTING WATER RESOURCES WITH HIGHER-DENSITY DEVELOPMENT, S.I.: USEPA.

30. USEPA, 2008. Urban Stormwater Management in the United States, Washington, D.C.: THE NATIONAL ACADEMIES PRESS.

31. USEPA, 2020. National Pollutant Discharge Elimination System (NPDES) Stormwater Rules and Notices. [Online] Available at: https://www.epa.gov/npdes/stormwater-rules-and-notices

32. USEPA, 2020. U.S. Environmental Protection Agency, Washington, D.C. "Protecting Water Quality from Urban Runoff.". [Online] Available at: https://www3.epa.gov/npdes/pubs/nps_urbanfacts_final.pdf

33. Weather-US, 2020. Average rainfall Washington, DC. [Online] Available at: https:// www.weather-us.com/en/district-of-columbia-usa/washington-climate\#rainfall 